\title{
Ecopreneurs' creation of user business models for green tech: an exploratory study in e-mobility
}

\author{
Nizar Abdelkafi* \\ Fraunhofer Center for International Management \\ and Knowledge Economy, \\ Neumarkt 9-19, 04109 Leipzig, Germany \\ Email: nizar.abdelkafi@imw.fraunhofer.de \\ *Corresponding author

\section{Erik G. Hansen} \\ Institute for Integrated Quality Design (IQD), \\ Johannes Kepler University (JKU) Linz, \\ Altenberger Straße 69, 4040 Linz, Austria \\ Email: erik.hansen@jku.at
}

\begin{abstract}
This paper examines ecopreneurship in established ventures that serve as early adopters of radical environmental technologies through so-called user business model innovation. Renewable e-mobility is identified as an appropriate application. The research methodology consists of two steps: a document analysis for developing a typology of ecopreneurs with user business models, and an in-depth case study analysis. We identify four patterns of entrepreneurial user business models in e-mobility: predominantly simple use, complementary business, feedback to core business, and additional business. We also explore the transformation path of the case company, which starts with simple use and then moves to the feedback to core business pattern. By drawing on insights from lead user theory in innovation management and sustainable entrepreneurship, we ground the new concept in extant literature and develop propositions. These propositions uncover some properties of ecopreneurs, the diffusion of environmental technologies, and industry transformations due to user business models.
\end{abstract}

Keywords: ecopreneurship; user business models; business model patterns; electric mobility; e-mobility; environmental technology; sustainability; transformation path; lead user theory; diffusion.

Reference to this paper should be made as follows: Abdelkafi, N. and Hansen, E.G. (2018) 'Ecopreneurs' creation of user business models for green tech: an exploratory study in e-mobility', Int. J. Entrepreneurial Venturing, Vol. 10, No. 1, pp.32-55.

Biographical notes: Nizar Abdelkafi is the Head of the research unit Business Model Engineering and Innovation at Fraunhofer Center for International Management and Knowledge Economy and a Senior Researcher at the Department of Innovation Management and Innovation Economics at the University of Leipzig. He holds an Industrial Engineering diploma from the National Engineering School Tunis, a Master degree in Business Administration from the Technische Universität München, and a PhD from the Hamburg University of Technology. He is interested in innovative business 
models, along with innovation and sustainability management and has published his research in two books, several international journals such as Organization \& Environment, International Journal of Innovation Management, Creativity and Innovation Management and IEEE Transactions on Engineering Management, as well as over 40 conference papers and book chapters.

Erik G. Hansen is Full Professor and Head of the Institute of Integrated Quality Design (IQD) at Johannes Kepler University (JKU) Linz, Austria. Additionally, he is a Visiting Professor at the Centre for Sustainability Management (CSM), Leuphana University of Lüneburg, Germany. His research focuses on sustainability-oriented innovation management at the level of products, product-service systems and business models as well as management systems in support of these processes. He is a member of the editorial board of Business Strategy and the Environment. He teaches on Doctorate, Master and Bachelor levels at JKU and in the MBA Sustainability Management programme at Leuphana University Lüneburg. Previously, he was a Visiting Scholar at Doughty Centre for Corporate Responsibility at Cranfield University, UK. He received his doctoral degree at Technische Universität München (TUM), Germany.

This paper is a revised and expanded version of a paper entitled 'User business models for ecopreneurship - an exploratory study in e-mobility' presented at Leuphana Conference on Entrepreneurship (LCE2016), Lueneburg, Germany, 14-16 January 2016.

\section{Introduction}

Environmental technologies can generate new opportunities for ecopreneurship (Doranova et al., 2012). An environmental technology "includes techniques, products and knowledge-based services for the avoidance, reduction or elimination of ecological damage or the recovery of already damaged environmental functions and thus contributes to sustainable use of natural resources" [Weinberger et al., (2012), p.33]. To leverage these technologies, companies can pursue reactive, anticipative, or innovative strategies (Noci and Verganti, 1999). Companies are reactive when they embrace the new technology as a response to an external stimulus such as an environmental pressure group or legislation. They are anticipatory when they leverage environmental technologies early on to achieve a competitive advantage. Companies are innovative when they define environmental performance as their top priority and develop or take up a new environmental technology. Which strategy a company should implement depends, among other things, on where the environmental technology is positioned on the diffusion curve. Companies embark on reactive strategies when technology adoption is at an advanced stage, allowing them to draw on a large body of knowledge based on the experiences of their peers with the technology. Those companies with anticipatory and innovative strategies must, however, cope with the economic risk resulting from the unavailability of such knowledge. These companies produce environmentally relevant knowledge through creativity and entrepreneurial thinking.

This research focuses on companies with anticipatory and innovative strategies, in other words, when the (premature) environmental technology is at an early stage of the 
diffusion curve and the potential for entrepreneurship is relatively high. In particular, this research deals with ecopreneurship (Schaltegger, 2002; Schaper, 2002) that results in the creation of new business models based on the innovative use of environmental technologies. While we focus on environmental technology and therefore ecopreneurship (e.g., Schaltegger, 2010), it should be mentioned that we also look at those technologies with a significant positive social impact and therefore can indeed be considered sustainable. Electric mobility (e-mobility) significantly reduces exhaust gases and therefore considerably improves urban air quality and reduces health risks (particularly due to diesel vehicles). Note that "akin to entrepreneurship, the term ecopreneurship is often used to describe investing in, or starting enterprises related to, natural resources rather than innovating as such" [Gunderson, (2013), p.910]. Furthermore, we only focus on new business models driven by established, not by startup companies. As a result, this paper uses three main concepts - environmental technology, business models (e.g., Schaltegger et al., 2016a; Johnson, 2010), and ecopreneurship (e.g., Schaltegger and Wagner, 2008; Schaper, 2005/2010) - to develop a new type of business model we call user business models for ecopreneurship.

E-mobility is an environmental technology that provides an appropriate context for this research. First, e-mobility fosters environmental sustainability when green electricity is used (e.g., Augenstein, 2015). Second, it is a systemic innovation that can initiate an enduring change of the whole mobility system (Abdelkafi et al., 2013), thereby transforming the value chains of producers and users (both business users as well as end consumers). As a result, e-mobility will necessarily drive entrepreneurship that creates new business models (e.g., Wells and Nieuwenhuis, 2015) to make the system function as a whole. Third, the diffusion level of e-mobility is still lower than predicted, making the role of users (here entrepreneurs rather than private consumers) and their business models especially important. Technological advancements have been, so far, at the focus of e-mobility research, but research on business models for e-mobility requires increased attention. Because of its transformative character, e-mobility calls for new business models, also in established user firms. E-mobility thus defines an ideal context for a better understanding of the phenomenon of user business models for ecopreneurship.

In general terms, the paper's main thesis is that it is not only the companies directly involved in developing new environmental technologies or products and services that require innovative business models, but also 'users' who want to be early adopters. Consequently, we are looking at the business-to-business context and consider ecopreneurs to be users when they integrate an environmental technology into their business models in a market phase where it is generally not yet considered economic in conventional terms. We are interested in companies that adopt and implement an environmental technology by leveraging business model innovation.

This paper aims to answer two main research questions. First, what are the key patterns of user business model innovations in e-mobility and what are the transformations that ecopreneurs can follow to implement these business models? Second, can we leverage the particular insights derived from the context of e-mobility to derive propositions on ecopreneurship and user business models that can hold in contexts shaped by other environmental technologies?

This paper contributes to the literature in four ways. First, it introduces user business models for ecopreneurship as a new concept to the literature. Second, it identifies patterns of entrepreneurial user business models in e-mobility. Third, it goes beyond product innovation to consider process innovation (such as the use of renewable e-mobility within 
companies) as well as the related business model changes to be a new source of innovation and thus entrepreneurial activity. Fourth, it capitalises on the patterns identified in the study to investigate potential pathways taken by users (i.e., entrepreneurs) to transform their established business models. An in-depth case study analysis illustrates how ecopreneurs transform their business models by using e-mobility as an environmental technology. Thus, this research contributes to the literature by showing that innovative business models are not only relevant for producers of environmental technology, but also for users planning to use environmental technology before its actual maturity.

The paper is structured as follows. Section 2 provides some background information on the main concepts of this research: e-mobility, ecopreneurship, and business model innovation. Section 3 describes our exploratory research methodology based on an intensive internet search and an in-depth case study. Section 4 presents the main findings; it identifies the patterns of user business models for ecopreneurship and discusses the transformation of a Germany-based company in the health sector toward a sophisticated user business model promoting environmental sustainability. Section 5 discusses the key results and elaborates research propositions that are independent of the environmental technology in question. In particular, we draw on lead user theory from innovation management and relate our findings to current frameworks on ecopreneurship to reflect on ecopreneurs and user business models. Finally, Section 6 summarises the key insights and presents directions for future research.

\section{Background}

\subsection{E-mobility as a context}

E-mobility is a systemic innovation that involves the use of electric vehicles such as e-cars, e-bikes, e-busses, etc. It is systemic because the new technology can only be implemented by the interplay of many actors (Abdelkafi et al., 2013). These actors are not only automobile manufacturers and suppliers, but also utilities, electricity charging stations, service providers, and many other players. E-mobility leads to a zero local emission because electric engines do not emit carbon dioxide or carcinogenic exhaust gases (e.g., Abdelkafi and Täuscher, 2015). E-mobility is considered an environmental technology because it has the potential to reduce environmental damage (e.g., Bohnsack et al., 2014).

E-mobility currently faces a diffusion challenge. For example, the German government has set a goal of having one million cars on German roads by 2020 (Nationale Plattform Elektromobilität, 2014). However, this objective is far from being fulfilled. Technical limitations (e.g., short driving range of e-vehicles; long charge times for batteries, limited battery performance at low temperatures), and a relatively high price and lack of infrastructure have made it little attractive to the market for both buyers and users (e.g., Bohnsack et al., 2014).

E-mobility will lead to many transformations in the automotive value chain (e.g., Henzelmann and Grünenwald, 2011). First, e-mobility results in new players entering the industry. For instance, Tesla is a relatively new US car manufacturer that launched its business with luxurious electric cars for the premium customer segment. Now Tesla is also a manufacturer of middle class cars and thus a serious competitor to many incumbent 
OEMs that have been in the automotive business for more than a century. Furthermore, though utilities and energy companies have not traditionally participated in the conventional car business, with the growth of e-mobility they can claim an important role in the value chain, for example, by installing and operating the charging infrastructure. Second, car producers rely on a large network of automotive suppliers, many of them producing components for the internal combustion vehicle. These suppliers must transform their business models if they are to be active in the new value chain. Also the service providers downstream in the value chain have to rethink their business models because the electric car requires less repair and maintenance services than the conventional car. Third, value is migrating from car producers to other players. The value of the battery is about one-third the value of the whole electric vehicle (Ernst et al., 2012), and electronic producers such as Panasonic, Samsung, and LG are moving into this business, not car manufacturers. In other words, if sales related to e-vehicles grow in the future, battery producers will play a greater role in the value chain as they generate the component with the highest value in the car. All these factors will lead to major structural transformations and a redistribution of power among the actors in the automotive industry. These transformations can drive entrepreneurship, in particular green entrepreneurship, if the positive environmental effects are leveraged appropriately.

It is worth noting that these transformations in the automotive industry tend to affect producers more than customers. Nevertheless, for a new technology to substitute an old one, it should be superior in at least one or a few dimensions valued by the customer. For a technology to be disruptive, it must not only replace an old technology, but also lead to new entrants to the market displacing established firms (Christensen, 1997). E-cars, however, do not seem to be disruptive to the automotive industry. Its value is still unclear for many users, as conventional cars can provide higher performance for less money. Government subsidies or regulation can be a solution to this challenge, as the renewable energy law in Germany demonstrates. More desirable is, however, the initiation of a selfreinforcing mechanism based on user business models that drives market development through entrepreneurial activity.

E-mobility, as a technology with high potential for achieving green transportation, has been long discussed in academia and the industry. In Germany, significant public funding has flowed into e-mobility research. In spite of this investment, initial goals have not been achieved as car manufacturers have factually ignored the technology to a large extent. The limitations of the new technology, though normal in its introduction phase, and the absence of producer business models that can compensate for these limitations or capitalise on the strengths of e-mobility (Abdelkafi et al., 2013) may explain why the automotive industry is cautious about taking more risks. The focus of car manufacturers has been directed more toward developing their own business models. For instance, BMW envisaged a model giving electric car owners access to a conventional car whenever they have to drive long distances to compensate for driving range limitations (Abdelkafi et al., 2013). Renault leases the battery to its customers instead of selling it, reducing the car initial price in an attempt to overcome buying obstacles.

Obviously, these business models are important, and producers should tweak them until they find the right formula. From a diffusion perspective (Rogers, 2003), however, focusing solely on producers is not enough, as the user's viewpoint should also be taken into account. Studies on user acceptance generally focus on the individual customer. For example, Will and Schuller (2016) examine user acceptance of smart charging stations for electric vehicles. Other studies (e.g., Bozem et al., 2013) demonstrate that customers 
only drive on average $50 \mathrm{~km}$ per day, making e-cars attractive in spite of their limited driving range. Other publications show that electric cars can be integrated into car-sharing services (IEA, 2012), so that customers can use the e-cars without having to incur the purchase cost. In Germany, however, about $60 \%$ of new cars are not sold to private customers, but to business car fleets (Riedel et al., 2014). Business customers would seem, therefore, to provide much better leverage than private customers for the diffusion of electric cars. Nevertheless, adopting a new technology is not easy, and companies have to rethink their processes to integrate the new technology in their business. Therefore, in our research, we propose to turn the entrepreneurial perspective from the producer to the business user of e-mobility devices or services. More importantly, ecopreneurs seem to be an e-mobility customer group that can adapt their business models in order to take up an environmental technology.

\subsection{Ecopreneurship and business model innovation}

\subsubsection{Ecopreneurship}

Shane (2003, p.4) defines entrepreneurship as "an activity that involves the discovery, evaluation and exploitation of opportunities to introduce new goods and services, ways of organizing, markets, processes, and raw materials through organizing efforts that previously had not existed". Following Lambing and Kuehl (1997), Schaltegger (2010, pp.77-78) notes that entrepreneurship can be defined in different ways: the process of creating a new company, the process of expanding business, the process of changing existing consumption and production patterns, the process of linking inventions with market success, or the leadership process of building up teams. Thus, entrepreneurship is not only linked to the foundation of new businesses and start-up ventures, but also involves the entrepreneurial function of established small and medium-sized companies, particularly through their owners, who are often owner-managers.

Consequently, in its broad sense, entrepreneurship is related not only to new, but also to incumbent firms. As entrepreneurs, ecopreneurs bridge activities between suppliers and customers, and because of their focus on ecological issues, they build bridges between environmental progress and market success [Schaltegger and Wagner, (2008), p.30]. According to Isaak (1998, p.113), "to become an ecopreneur is an existentialist commitment in which the entrepreneur knows he or she will never reach the ideal, but that very ideal of sustainability gives meaning to everything the ecopreneur does upon the earth". Ecopreneurs are crucial change agents that strive to achieve a more sustainable future by transforming their businesses or creating new green startups (Walley et al., 2010).

Hansen and Klewitz (2012) find in their comparative longitudinal case study that established SMEs, often in support of intermediary organisations, pursue proactive green strategies and pioneer sustainability solutions both internally (e.g., process and organisational innovations) and externally through market products (e.g., a sustainable product line or an environmental technology). Thus, one role that ecopreneurs with their proactive orientation could take on is helping to diffuse promising environmental technologies through early adoption. Consider Christensen et al.'s (2012, p.499) observation: "innovative technologies that have the potential to meet key sustainability targets are not easily introduced by existing business models within a sector, and that only by changes to the business model would such technologies become commercially 
viable". Research on technological innovation, in general, supports this perspective. It shows that it is often not enough to develop innovative or even radically new technologies, because their market introduction often fails due to incompatibility with the producer's existing business models. In such cases, it is therefore the business model that determines the success of new technologies (e.g., Chesbrough, 2006). Eco-innovation is thus about new environmental technology and a new business model. In this context, Klewitz and Hansen (2014) find that companies founded by sustainable entrepreneurs or ecopreneurs constitute a category of small and medium-sized firms that link business model innovation with the radical change of processes, products, and organisational forms in order to achieve their sustainability goals: "while this seems to emphasize the creation of new ventures, also conventional SMEs can radically change by remodelling their business models. Business model innovation can enable conventional firms to radically change processes, products, and organizational forms in order to more successfully integrate sustainability into core business ..." [Klewitz and Hansen, (2014), p.71].

\subsubsection{Business models}

Research on business models and on their innovation has become increasingly important since the late 1990s (e.g., Demil et al., 2015). In simple terms, a business model describes the way companies make money. More specifically, a business model shows how companies create, deliver, and communicate a value proposition - and capture value out of it (Abdelkafi et al., 2013). Business models can be the subject of the company's innovation endeavours, thus going beyond a focus on more traditional product and process innovations. As such, the business model represents a powerful concept that links different components of the business and illustrates the logic of the firm's value creation. "The study of business models involves exploring how firms do business at the system level" [Demil et al., (2015), p.1]. Business model patterns or archetypes have been shown to be highly relevant to research on business model innovation (Abdelkafi et al., 2013; Gassmann et al., 2013). These patterns can support the process of innovation and inspire managers who are looking for new ways of doing business. Thus, pattern identification should be considered a fundamental component in business model research as it promotes analogical thinking through the transfer of patterns across industry sectors (e.g., Abdelkafi et al., 2013; Enkel and Mezger, 2013; Martins et al., 2015).

Research on sustainability management identified early on the important role of the business model concept for sustainability-oriented innovation (Hansen et al., 2009; Lüdeke-Freund, 2009), thereby leading to an emerging research field, which is often referred to as business models for sustainability (Bocken et al., 2014; Boons and Lüdeke-Freund, 2013; Schaltegger et al., 2012, 2016a, 2016b). Many authors identify business model archetypes (e.g., Bocken et al., 2014; Wells, 2013). For example, Wells (2013) defines six major principles that underpin business models for sustainability: resource efficiency, social relevance, regional localisation and engagement, product longevity, ethical sourcing, and work enrichment. In the context of systemic ecoinnovation, Doranova et al. (2012, p.46) identify nine types of business models: greener product and process-based business models, waste regeneration systems, alternative energy-based systems, efficiency optimisation by ICT, functional sales and management services model, innovative financing schemes, new sustainable mobility systems, industrial symbiosis, as well as green neighbourhoods and cities. Business models for 
sustainability generally integrate environmental and social issues. In this paper, while we are aware of the positive impact of environmental orientation on the social component, we focus on the environmental aspect. Abdelkafi and Täuscher (2015) argue that business models for environmental sustainability integrate two types of value propositions: one for the customer and one for the environment. Thus, a reinforcing loop should be designed in the business model to drive the value to the environment and to the company when value is created for the customer.

Although examples of user business models are relatively common among the archetypes identified in the sustainability literature (Bocken et al., 2014), so far no research study has been dedicated to an investigation of this type of business models, especially in relation to ecopreneurship. User business models are by no means a new phenomenon. Advances in internet technology in the late 1990s, for instance, led to new user business models for many incumbent firms and startup companies (e.g., Currie, 2004), a process now known as digital transformation. Whereas there is no doubt that internet-user business models have supported the diffusion of internet technology, they were not a necessary condition. In the case of systemic environmental technologies, however, user business models are required to support technology diffusion. In effect, users create the demand for these technologies, and this demand triggers learning effects and scale economies that further boost technology development. As a result, the success of the environmental technology in end-user markets can be significantly accelerated when ecopreneurs spur diffusion in business-to-business markets by developing appropriate user business models.

\section{Methodology}

To identify patterns for user business models and to discover potential transformation paths, this paper applies a qualitative research methodology combining exploratory research using publicly available sources and in-depth case study analysis. The analysis of publicly available sources enables us to recognise general patterns of user business models (Eisenhardt and Graebner, 2007) while the case study illustrates how ecopreneurs transform their business models to user business models embracing environmental technologies.

\subsection{Step 1: Identification and selection of cases through publicly available sources}

To identify companies using e-vehicles in Germany, in April 2015 we conducted a web search and posted questions on open platforms related to the automotive industry. Our search returned 33 companies. The search process was stopped when it became increasingly difficult to find new cases. Note that not all companies actually publish whether they use e-vehicles or not. Our objective was to identify entrepreneurial small and medium-sized enterprises (SMEs) whose managers can be considered ecopreneurs due to their innovative and proactive way of incorporating new environmental technology into their business models. An initial sample analysis shows two important differences between the cases. First, some companies received government subsidies to buy e-vehicles while others did not. Second, some companies were innovative in integrating 
e-mobility into their business, whereas others just substituted e-cars for conventional cars or added e-bikes and e-cars to their fleets. Companies that have done more than merely replace gasoline-powered cars with electric vehicles are considered innovative. The evaluation whether a company is innovative or not was done systematically by means of the following questions. Did the introduction of e-vehicles lead to a change in the company's value proposition? How did the company adapt its value creation processes after the introduction of e-mobility? Is there any change in customer segments or distribution channels? Did the company use e-mobility to communicate proactively its environmental orientation, and if so how? Has there been any innovative change in the profit formula since the implementation of e-mobility? A discussion of these questions between the researchers, who relied on the information available in the internet, led to a categorisation of the user business model as innovative or not.

Table 1 Twelve innovative companies in the area of e-mobility (based on internet research)

\begin{tabular}{|c|c|c|c|}
\hline No. & Company & Business/sector & E-mobility practices \\
\hline 1 & Schüren Bakery & $\begin{array}{c}\text { Food } \\
\text { service/trade }\end{array}$ & $\begin{array}{l}\text { Providing charging stations for customers and } \\
\text { non-customers } \\
\text { - Proprietary production of electricity with } \\
\text { photovoltaic solar power infrastructure } \\
\text { - Diverse key card-based systems for users of the } \\
\text { charging infrastructure } \\
\text { - E-cars and vans for the distribution of bakery } \\
\text { products among points of sale }\end{array}$ \\
\hline 2 & Aaglander & Hotel business & $\begin{array}{l}\text { Renting electrically-powered carriages for trips } \\
\text { and tours } \\
\text { - The } 5 \mathrm{kWh} \text { battery of the carriage can deliver } \\
\text { energy for about } 8 \text { hours (highest speed: } 20 \\
\mathrm{~km} / \mathrm{h} \text { ) } \\
\text { - Slow-paced and soundless means of transport to } \\
\text { enjoy the landscape of the Franconian region } \\
\text { - Proprietary development of the power unit }\end{array}$ \\
\hline 3 & Solar und Mobil & $\begin{array}{l}\text { Heating } \\
\text { engineering } \\
\text { services }\end{array}$ & $\begin{array}{l}\text { - Planning, sales and assembly of solar panels } \\
\text { - Consulting services, sales, and maintenance of } \\
\text { e-vehicles such as cars, bikes, vehicles for } \\
\text { elderly people, etc. } \\
\text { - Targeted cooperation with selected partners for } \\
\text { every e-vehicle model in the portfolio. }\end{array}$ \\
\hline 4 & Stapel GmbH & $\begin{array}{c}\text { Sanitary and } \\
\text { heating } \\
\text { solutions }\end{array}$ & $\begin{array}{l}\text { Combine e-mobility with electricity from solar } \\
\text { panels } \\
\text { - Testing, renting, leasing, financing, and buying } \\
\text { e-bikes } \\
\text { - Construction of solar carports and solar e-bike } \\
\text { charging stations }\end{array}$ \\
\hline
\end{tabular}


Table 1 Twelve innovative companies in the area of e-mobility (based on internet research) (continued)

\begin{tabular}{|c|c|c|c|}
\hline No. & Company & Business/sector & E-mobility practices \\
\hline 5 & Trimo Cargo & Logistics & $\begin{array}{l}\text { - Cargo bikes and enhanced e-cars (Renault } \\
\text { Twizy) for small to medium cargo transport } \\
\text { city-wide } \\
\text { - Express logistics services, gastronomic delivery } \\
\text { services } \\
\text { - Transport logistics in areas of the city that are } \\
\text { difficult to reach with conventional vehicles }\end{array}$ \\
\hline 6 & Trimo Tours & $\begin{array}{l}\text { Passenger } \\
\text { transport and } \\
\text { tourism }\end{array}$ & $\begin{array}{l}\text { - Provides e-three wheelers that can serve as } \\
\text { shuttle, taxi and for adventure trips and city } \\
\text { tours } \\
\text { - Works together with eldercare centres and } \\
\text { offers selected routes for public transportation. }\end{array}$ \\
\hline 7 & $\begin{array}{c}\text { Solar Bahn Bad } \\
\text { Bevensen }\end{array}$ & $\begin{array}{l}\text { Passenger } \\
\text { transport and } \\
\text { tourism }\end{array}$ & $\begin{array}{l}\text { - Conducts on-street, solar-powered tourist train } \\
\text { with stops near hospitals, hotels, etc. } \\
\text { - Public-private arrangement concerning building } \\
\text { and servicing of the train }\end{array}$ \\
\hline 8 & $\begin{array}{l}\text { Autodienst } \\
\text { Achenbach }\end{array}$ & $\begin{array}{l}\text { Automobile } \\
\text { repair and } \\
\text { maintenance }\end{array}$ & $\begin{array}{l}\text { E-car as a replacement vehicle in car fleet, with } \\
\text { advertising for the company } \\
\text { - Offers maintenance and repair services for } \\
\text { e-cars } \\
\text { - Sustainable disposal of vehicle waste }\end{array}$ \\
\hline 9 & Prima Clima Mobil & $\begin{array}{l}\text { Passenger } \\
\text { transport } \\
\text { logistics }\end{array}$ & $\begin{array}{l}\text { Runs a taxi fleet consisting of natural gas, } \\
\text { hybrid, and e-cars, with the long-term goal of a } \\
\text { completely e-car fleet } \\
\text { - Pays taxi drivers a fair fixed income }\end{array}$ \\
\hline 10 & $\begin{array}{c}\text { BeoPlast } \\
\text { Kunststofflösungen }\end{array}$ & $\begin{array}{l}\text { Plastics } \\
\text { production } \\
\text { industry }\end{array}$ & $\begin{array}{l}\text { - Produces plastic without } \mathrm{CO}_{2} \text { emissions } \\
\text { - Runs a company's fleet consisting only of } \\
\text { e-vehicles powered by solar panels } \\
\text { - Customers and employees can recharge their } \\
\text { e-vehicles for free using the company } \\
\text { infrastructure. }\end{array}$ \\
\hline 11 & $\begin{array}{l}\text { eMio } \\
\text { Roller-Sharing } \\
\text { Berlin }\end{array}$ & $\begin{array}{c}\text { Scooter sharing } \\
\text { services }\end{array}$ & $\begin{array}{l}\text { - Runs e-motor scooter sharing service via } \\
\text { smartphone } \\
\text { - Replaces empty batteries so customers are not } \\
\text { burdened with charging them }\end{array}$ \\
\hline 12 & $\begin{array}{l}\text { PMK-Pflegedienst } \\
\text { (case study } \\
\text { company) }\end{array}$ & $\begin{array}{l}\text { Healthcare/ } \\
\text { eldercare } \\
\text { sector }\end{array}$ & $\begin{array}{l}\text { - Provides health care services for elderly people } \\
\text { - Produces electricity by means of solar panels } \\
\text { - Has three e-cars in its car fleet and plans its } \\
\text { expansion }\end{array}$ \\
\hline
\end{tabular}


The companies were classified by two dimensions: reception of government subsidies (yes/no) and innovative use of e-mobility (yes/no). The matrix leads to the generation of four categories of e-mobility user companies. The six companies in the first category, which we call 'e-mobility free riders', received government subsidies and were considered not innovative. The second category involves companies that received subsidies, but were innovative in using e-mobility. This category, called 'e-mobility improvers', contains the smallest number of cases in the matrix; only four. The third category, referred to as 'e-mobility simple users', includes companies that bought their vehicles with their own money, but were not innovative. The fourth category consists of the most interesting cases, with 12 companies that actually did not did receive government subsidies, but were innovative in using e-mobility (Table 1). These companies were examined more closely using the information available in the internet in order to develop a typology of user business model patterns.

\subsection{Step 2: In-depth case study}

From the sample, we selected PMK-Pflegedienst GmbH, an innovative company with a strong environmental and entrepreneurial orientation in order to conduct an in-depth case study (e.g., Yin, 2009). This is an SME located in Lüneburg, Lower Saxony, Germany, with about 40 employees. It offers services for elderly people in need of healthcare. In this business field, price pressures are extremely high because of the stringent regulations imposed by health insurance companies. The owners also run the company and have a vision of fostering sustainability in their company while achieving a high degree of energy autonomy. In spite of the financial risks associated with environmental technologies, they are willing to experiment with e-mobility and related technologies. The data for this case study was collected from a number of sources:

1 interview sessions with the business owners

2 company documentation

3 onsite observations

4 a five-hour workshop session on business models conducted in June 2015, involving the authors, the company owners, and graduate students of sustainability

5 the so-called Energy Café organised in September 2015 at a local conference with the participation of the authors, practitioners, academics, and policymakers, where the company case was presented and discussed thoroughly.

Thus, the sources of data collection are triangulated. Due to the strategic nature of the topic, only the business owners were involved as key informants in the study. Furthermore, the interviews were not recorded and transcribed. Instead, the researchers took notes and wrote interview or workshop minutes as documentation of the collected data.

\section{Findings}

There are two main findings. First, we found innovative patterns of user businesses, uncovering opportunities for companies that aim to develop user business models around 
environmental technologies. Second, our analysis of the in-depth case study shows a possible transformation strategy an ecopreneur can use to implement a user business model for environmental sustainability.

\subsection{Typology of user business models in e-mobility}

The sample of e-mobility cases leads to the identification of four patterns of user business models. These patterns are categorised by means of two dimensions:

1 value proposition

2 value creation.

We chose value proposition as it is usually considered as the central element when transforming from conventional to sustainability-oriented business models, particularly in more significant or 'proactive' changes (Schaltegger et al., 2012). Furthermore, given our focus on the deployment of green technologies (e.g., electric vehicles) in the organisational processes, we also focus on the value creation dimension as it covers the organisation's infrastructure and assets. Note, however, that value creation and value proposition are only two elements out of many that are part of the business model. Other elements such as the value capture (revenue streams and cost structure) or value delivery (e.g., customer interface) are also relevant elements, but they are not focused here.

E-mobility may change the value proposition and/or value creation either completely or only to a small extent, resulting in a $2 \times 2$ matrix. When both value dimensions either do not change at all or only to a small extent, the pattern is called '(predominantly) simple use'. When both change, the pattern is referred to as 'additional business model'. In the event that the value proposition changes whereas the value creation remains practically the same, the pattern is named 'complementary business'. Finally, when the value proposition provided to the customer stays almost the same whereas the value creation process changes, the pattern is called 'feedback to core business' (Figure 1):

1 The '(predominantly) simple use' pattern (Q1): in this pattern, e-mobility supports the core business. It changes the infrastructure component, for example, by replacing the vehicles in a conventional fleet by e-vehicles. The impact on both business model elements is small. A typical example would be a taxi company that introduces e-cars to its fleet (e.g., Prima Clima Mobil), or a logistics company that uses e-vehicles to provide its services inside the city (e.g., Trimo Cargo). Another example would be a pizza service company that delivers meals by switching at least some of its bikes from conventional to e-bikes. Note, however, that the companies implementing this pattern (as were all of the firms in our study) were considered to be innovative to a certain degree in using e-mobility.

2 The 'complementary business' pattern (Q2): companies implementing this pattern add new service products related to e-mobility. These services are a logical extension of the value proposition. For example, repair services for e-bikes can be added to those for conventional bikes. In our sample, the Aaglander Hotel provides its customers with tours and trips in electrically powered carriages, a complementary business in the tourism sector. Thus, the new e-mobility-based product is aligned with the company's value creation approach; only the value proposition is adapted. 
3 The 'feedback to core business' pattern (Q3): this pattern results in radical changes in the company's value creation approach. E-mobility has a major influence on the core logic of the business. The company's experiences with e-mobility lead to an enduring change, and the company gradually evolves to a sustainable business model, although the core value proposition remains unchanged. This pattern relates to the case study company, which is discussed in the next section.

4 The 'additional business model' pattern (Q4): in this pattern a company introduces a new e-mobility-based business model. The new value proposition offered to the customer is often unrelated to the core business of the user firm. For example, the Schüren Bakery developed a new business model that is far removed from making and selling bread to customers: selling electricity for e-vehicles at charging stations installed near the bakery. E-mobility users may add new businesses in a field in which they could gain expertise due to their own experience. We identify five types of new value propositions: logistics, charging station operators, consulting services, fleet management and sharing services, as well as integration services.

Figure 1 User business model patterns in e-mobility

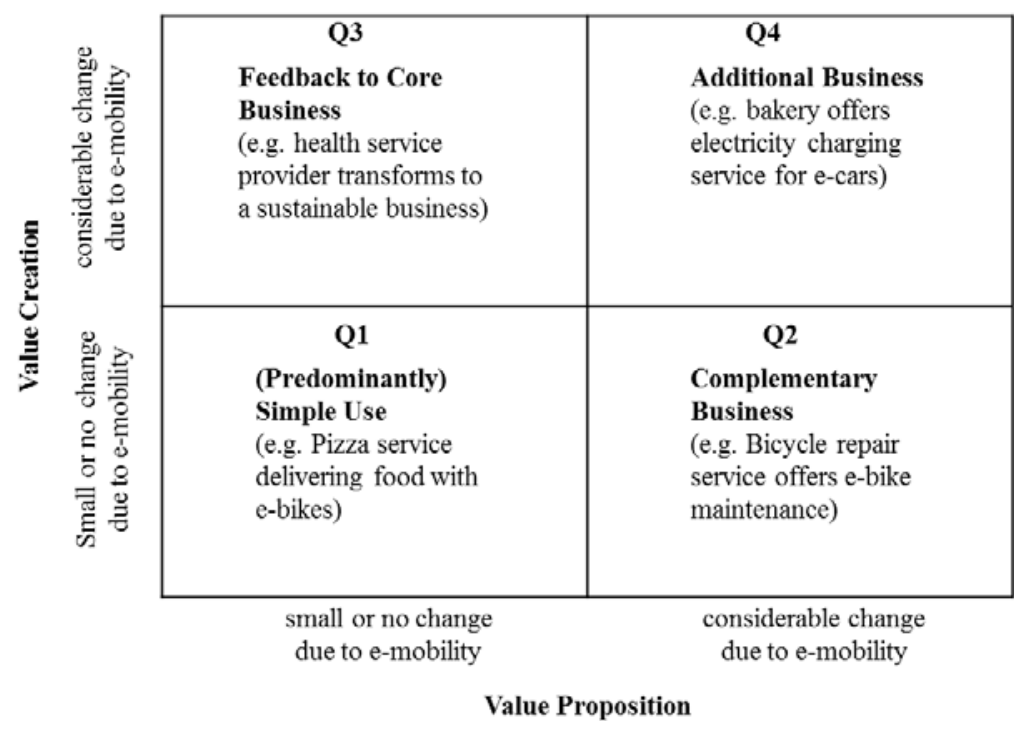

Companies may not exclusively use one pattern or another, but switch between patterns over time. Nevertheless, the starting point is likely to be the patterns '(predominantly) simple use' or 'complementary business'. These patterns are straightforward and easier to implement than the other two. One scenario would consist of three steps. First, the company starts as a simple e-mobility user. Then, it gradually evolves to being a sustainable business by fostering its environmental orientation (feedback to core business). Finally, as expertise with e-mobility grows, it develops a consulting service to advise other companies planning to adopt the technology (additional business). Other paths are also possible. For example, a company may start with a complementary business (e.g., e-bike repair services) and then develop an additional business that is independent of its original business. 


\subsection{In-depth case study analysis: a transformation through ecopreneurship and user business models}

The in-depth case study illustrates the successful transformation of a medium-sized company in the health service sector through user business models to promote environmental sustainability.

Phase 1 Before the adoption of electric vehicles

PMK started as a simple user of environmental technologies other than e-mobility, namely solar energy (lower left quadrant Q1 in the typology matrix). Before it adopted e-mobility in 2011, the business owners had installed solar panels for the production of electricity for the operation of the company's building. Because the company produced much more electricity than required, the surplus was fed back into the power grid. However, a kilowatt sold by the company was cheaper than a kilowatt bought from the grid, and if the company could increase its electricity consumption in a way that reduces the use of other forms of energy, it could save energy costs.

Phase 2 Simple use of electric vehicles

To consume more self-produced electricity and reduce the consumption of fuel-based energy, the company decided to substitute e-vehicles for conventional cars. Recall that next to personnel costs, the largest item in the operating costs for the company is logistics, since as caregivers they render on-site services to elderly people. Thus, at first glance, e-vehicles seem advantageous because they have lower operational costs than conventional cars (due to lower energy and maintenance costs). Nevertheless, the purchasing price is higher, and investments in charging stations (three $11 \mathrm{~kW}$ wall boxes) are required. Since the e-cars they bought involve leasing the battery, additional costs are paid on a monthly basis. Each e-car has a $22 \mathrm{kWh}$ battery, meaning that a large portion of the energy that has been previously fed back into the power grid is now used for charging the cars.

Phase 3 Feedback to core business

As a result of these energy projects, the company became more committed to sustainability. This thinking has become so ingrained in the business owners' actions that they decided to switch to a more expensive green electricity provider. Now, the company envisages buying e-busses and installing a battery system to store the surplus electricity it had been feeding back into the power grid. Thus, the company transformed itself from a simple user business model to a one with a strong orientation to sustainability by leveraging feedback to core business (upper left quadrant Q3).

Phase 4 Generating ideas for future business model extensions

Currently, PMK is thinking of making the next transition by adding a new business. This would be a logical step as the company has accumulated expertise in e-mobility over time. During an innovation workshop that took place on the company site in June 2015, several new options were explored 
that would allow the company to extend its business model. One option closely investigated by the owners was adding businesses by using crowdfunding to finance the installation of solar panels on the roofs of surrounding buildings, charging stations, and car sharing collection locations. These potential future innovation pathways represent new value propositions through complementary or additional businesses (lower and upper right quadrants in the framework: Q2 and Q4).

Overall, the company constitutes a good case study that illustrates the transformation of a service company toward environmental sustainability by leveraging the business model transition from 'predominantly simple use' to 'feedback to core business' in the e-mobility context.

\section{Discussion}

Having demonstrated the existence of and, most importantly, the users' need for innovative business models to take up environmental technologies, it is important to relate the concept of user business models to the phenomenon of ecopreneurship as reported in the literature, namely to discover the properties of ecopreneurs and to reflect on the conditions that are conducive to the emergence of user business models.

\subsection{Radical environmental technologies as an opportunity for ecopreneurship}

An environmental technology that only solves a minor resource efficiency problem is unlikely to give rise to ecopreneurial activity driven by innovative user business models. On the contrary, systemic innovations, which involve producers, users, and infrastructure as in e-mobility, are more likely to require and generate innovative user business models. Because a new environmental technology is generally immature and cost-intensive at the beginning of its lifecycle, its environmental benefits may not compensate for the initial costs (e.g., Kley et al., 2011). In fact, in the case of e-mobility most electricity is still produced from fossil resources, making it questionable whether there is actually an environmental benefit. It is these entrepreneurs who are dissatisfied with the environmental impact of their business that are more likely to become early adopters of such radical environmental technologies, even if this requires a change of their business model.

As business models change over time, firms adapt their business models by selecting an appropriate transformation (or evolutionary) path (Morris et al., 2005; Sosna et al., 2010). A transformation path is a sequence of business model patterns implemented by the company. Companies may start with a pattern such as '(predominantly) simple use' or 'complementary business' and then develop their business model over time. Due to high risks at the early stages of technological development, some ecopreneurs conduct a set of small-scale tests before gradually extending their business model. Because users accumulate experience and knowledge, they can gradually improve their business models.

Proposition 1 An environmental technology that induces a system-level innovation creates opportunities for ecopreneurship. Ecopreneurs adapt their business models to successfully adopt this radical technology. Business 
model changes can follow transformation paths leading from the adoption of the new technology (simple use) to the change of the company's value proposition (complementary business) or transformation of the value creation (feedback to core business) to entirely new business (additional business).

\subsection{User business models and lead user theory}

\subsubsection{Lead user characteristics and the ecopreneur}

To better ground the concept of user business models, we draw on lead user theory by establishing an analogy between lead user innovation and user business models. Von Hippel $(1988,2005)$ studied lead users in the context of products and services. He differentiates between innovators in diffusion theory (see also Rogers, 2003) and lead users (von Hippel, 1988, 2005). Innovators in diffusion theory are defined as the very first adopters of innovation (Rogers, 2003). As such, they do actually not innovate. Lead users, on the contrary, create innovations since they design and produce new artefacts. Entrepreneurs who invent new ways of using an environmental technology as part of their ventures can be considered innovators in the sense of Rogers (2003), since they adopt a technological innovation very early in its lifecycle, but they can also be described as lead users since they exploit this innovation to design and create new business models.

Von Hippel (2005) defines lead users by means of two properties. First, lead users have big incentives to innovate and create a prototype, as they themselves are users of the product and benefit from it directly. Second, they are ahead of the mass market. They have needs that the mass market has not exhibited yet. As our case study shows, the business owners adopted a radical environmental technology and changed their business models due to their dissatisfaction with the status quo. Driven less by profit and more by a vision, these business owners are proud of their business model. This vision is nurtured by their willingness to make a contribution to the environment and society while becoming independent of energy producers. In the words of one of the business owners: "Our concept is a democratic act!". In this way, the business takes a political role and also establishes moral legitimacy, which is based on moral judgements on whether the institution's output, procedures and structures as well as the leaders' behaviour are socially acceptable (Scherer and Palazzo, 2011). In addition, the company is ahead of its competitors. In a sector where cost pressures are high and the innovation level is low, similar healthcare companies are expected to be conservative and reluctant to integrate new technologies. In sum, von Hippel's definition (2005) of lead user provides insights when it is transferred to business model innovation in our case study.

Entrepreneurs, in particular ecopreneurs, are by definition doers; they are not content with simply designing a user business model, but need to implement it to get real feedback from practice. In this sense, they are similar to lead users, who make their own physical prototypes because they want to use them (von Hippel, 2005). Business models are, however, intangible. Especially at their launch, they need a lot of fine-tuning before they can become profitable (e.g., Johnson et al., 2008). Therefore, we propose that most users who develop business models are more interested in pursuing an abstract objective than in achieving a direct benefit. In fact, because the technology is still at the beginning of its lifecycle, it is immature and cost-intensive, and entrepreneurs need to be strongly motivated to develop or adapt a business model around the new technology. This vision 
or conviction explains why entrepreneurs embark on developing new business models. In effect, while business models, per se, aim at generating money, successful entrepreneurs do not focus on short-term profits, but develop a vision that drives their endeavours. This perspective is also in line with the findings of Parrish (2010, p.512), who investigates cases where "contributing to improved ecological and social wellbeing is a primary purpose of the enterprise, and market-based income is valued as a means of achieving these ends".

Proposition 2 Ecopreneurs have an inner drive to adopt radical environmental technologies, even with a low maturity level. To enable successful adoption, ecopreneurs develop user business models that are ahead of the mainstream industry in which they operate.

\subsubsection{User business models, free revealing of innovation and diffusion}

Interestingly, ecopreneurs are likely to make their user business model accessible to others. For instance, the business owners in our case study intensively collaborated with the university and then presented their concept to a public audience at many conferences and workshops. This behaviour increases the likelihood that other companies will learn about their business model and implement a similar concept. In line with this observation, von Hippel (2005) found that lead users tend to not protect their designs, for example by applying for and filing patents. Instead, they share them free of cost with others. Lead users want as many potential developers as possible to have access to their designs so that the improvement cycles are accelerated, leading to a better prototype that they in turn can directly benefit from. Business models, however, are not patentable, at least in Europe. As such, they are not protected by intellectual property rights. Nevertheless, sophisticated business models are even more difficult to imitate (Teece, 2010) than products and services, as business models rely on intangible internal processes. In other words, ecopreneurs want to make their business models accessible to a wider audience and make a considerable effort to do so. We can now derive the third proposition:

Proposition 3 Ecopreneurs tend to disseminate their user business model prototypes and make them accessible to others, and so enable the diffusion of environmental technology.

Policymakers should be especially interested in identifying user business models in the area of environmental technologies, in particular e-mobility. They should be more attentive to sustainable entrepreneurship driven by user business models because of its potential to strengthen the diffusion of environmental technologies. Pattern replication of business models promotes technology diffusion and facilitates the achievement of political goals, for example the German government's goal of having one million e-vehicles on the road by 2020. As a result, policymakers should use public money not only to fund research in the technology itself, but also to capture the best practices of user firms that have succeeded in integrating the new technology in their business models and to support their company owners in diffusing these models. The insight from lead user theory, which was also confirmed by the case study, is that user companies are willing to share their experiences and freely reveal information about their user business models. Thus, the capture, analysis, and dissemination of user business models constitute a good strategy to accelerate the diffusion of new environmental technologies. 
Though ecopreneurs freely reveal their user business model innovation, the identification of the models can be challenging. Von Hippel (2005) suggests using instruments such as pyramiding to identify lead users; that, is to start at the base of the pyramid by asking informants with modest expertise in a specific field and then to climb the pyramid by finding at each step people with more expertise until lead users are identified at the top. This methodology can be applied to finding innovative user business models in a specific industry. While free revealing improves the potential for diffusion of user business models and the environmental technologies they are built around, we still need to better understand these diffusion processes. We recommend co-evolutionary analysis of the extent to which technologies and business models in an industry co-evolve and mutually influence each other.

\subsection{User business models and the diffusion process of environmental technologies through co-evolution with incumbents}

Our case study shows that ecopreneurs in young or small companies embraced e-mobility at an early stage as an environmental technology for greening their business, and they did this by adapting existing or creating new user business models. But the question is how exactly this process influences the broader market diffusion of e-mobility so that positive environmental and climate impacts can be generated on a significant scale. Could a first stage of diffusion be delivered by smaller companies followed by larger incumbent companies able to deploy environmental technologies on a greater scale? To answer this question, this section discusses the user business model concept in relationship with Hockerts and Wüstenhagen's (2010) co-evolutionary framework, which was originally developed in order to understand diffusion processes of sustainable products in business-to-consumer settings driven by the interplay of small ventures (so-called Davids) and large incumbents (or Goliaths). This framework shows that at early stages of the sustainability transformation of an industry, new entrants are more likely to pursue sustainability opportunities than incumbent companies, but that co-evolution between the emerging Davids and greening Goliaths lead to sustainability transformations.

This framework is applied to environmental technology diffusion while integrating the business model as an additional level of analysis (for recent approaches to co-evolution of business models for sustainability, see also Hannon et al., 2013; Schaltegger et al., 2016b). Small and young entrepreneurs, often driven by idealistic motives, play the role of catalyst for change in and beyond their industry and can initiate a wider diffusion of the environmental technology among businesses by pioneering user business models. Nevertheless, the adoption of environmental technologies for greening the business is, at its core, process innovation (value creation), and this is a strength of large incumbent firms (e.g., Markides and Geroski, 2005). Therefore, it would be expected that large firms would be able to catch up quickly.

Some young companies manage to scale up their businesses. As they accumulate experience and achieve higher economies of scale, they ultimately develop a more competitive product. For the company in our case study, this meant lower costs or more attractive elderly care services using solar e-mobility instead of combustion-based vehicles. This new business model of small and young companies can become a threat to incumbents who then have to invest in environmental technology as well. Thus, large companies come to mimic the value propositions of the young firms and are forced to 
adapt their business models. Overall, the co-evolution of emerging Davids and greening Goliaths are a key factor in driving the adoption of environmental technology.

Proposition 4 In the early stage of a new environmental technology, startups and young or small companies are more likely to change existing business models or develop new ones that enable the early adoption of radical environmental technology (i.e., developing user business models), because of their greater flexibility and the intrinsic motivation of the owner-manager. Large firms observe this success and may be forced to transform their own business models to adopt radical technologies. This leads to a higher rate of adoption and diffusion of the environmental technology and can contribute to economies of scale and technology maturation, as well as ultimate take-up in consumer markets.

In this regard, Hockerts and Wüstenhagen (2010, p.482) mention that "rather than exclusively listening to the voice of incumbents (which is arguably a popular approach in politics) or putting all eggs in the basket of start-ups, policymakers would be well advised to consider the specific strengths and weaknesses of both options and to pursue a portfolio that provides simultaneous incentives for greening Goliaths and emerging Davids". In other words, policymakers should allocate their funding programs between small or young user firms of environmental technologies and those that are larger.

A second means of co-evolution and technology diffusion is the development of entirely new businesses by ecopreneurs, particularly in other industries based on the environmental technology (e.g., charging infrastructure offered by a bakery), thus accelerating the adoption of the new environmental technology. By creating an additional business (Q4), young and small companies can be disruptive to large companies from other industries. This can lead to green transformations not only in the company's industry, but in others as well.

\section{Conclusions and directions for future research}

This paper introduces user business models to the literature on ecopreneurship and explores their contribution to environmental sustainability. If new technology has a positive environmental impact, then user business models are even more important than producer business models. Four patterns for user business models were identified: (predominantly) simple use, complementary business, feedback to core business, and additional business. These patterns can be combined in a sequence to form a transformation path. The case study illustrates an example of a company from the health service sector that embarked on such a transformation path, starting with '(predominantly) simple use' and evolving to 'feedback to core business'.

We develop four propositions using innovation management research on lead users and the framework by Hockerts and Wüstenhagen (2010) on the role of incumbents and new entrants in sustainable entrepreneurship. These propositions relate to the main condition under which an environmental technology can give rise to user business models; the paths available for user business model transformation; the properties of ecopreneurs who design such business models and their contribution to diffusion; and the co-evolution of young or small companies with large established ones. 
Systemic innovations related to environmental technologies may be more conducive to the creation of user business models than technologies that solely focus on solving a small resource efficiency problem. In addition, ecopreneurs have an inner incentive to implement radical new or even immature environmental technologies. Their user business models are ahead of their industry. Ecopreneurs also freely reveal information about their innovative business models. Moreover, user business models seem to be a necessary condition for the diffusion of environmental technologies. Small and young companies are more likely to be the first actors who adopt user business models to take up an environmental technology. Established large players react and often catch up, leading to the transformation of the industry. Companies using environmental technology to add a new business to their core business can help initiate a transformation in an industry that is far from the original industry in which they operate.

In future, more case study research should be conducted in the area of e-mobility and other environmental technologies to investigate the concept of user business models more thoroughly. Our work leads to the identification of a number of new research questions. First, what are the transformation paths that firms actually embark on? Second, are there additional patterns of user business models that can be observed in relationship to other environmental technologies? Finally, to what extent can user business models accelerate the diffusion of environmental technologies? Here, we are particularly interested in analysing the chain from the early take up of radical environmental technologies by entrepreneurial businesses to the subsequent take-up by incumbent businesses on a larger scale, to their ultimate diffusion in consumer markets. Future research should also look into the specific role and strength of incumbents, particularly regarding upscaling of their user business models. For example, in the parcel delivery and broader logistics industry, the recent case of the German corporation Deutsche Post (DHL) is of particular interest [DHL, (2016), p.114]. They developed a strategy to change their delivery system to an electric truck and car fleet but were not given any support from the German automotive industry (who was not willing to develop e-vehicles). As a result, they acquired a start-up company and started producing their own e-trucks. Subsequently, they sold electric trucks to other companies, in fact leading to the founding of an 'additional business' (Q4). This puts pressure not only on their competitors in the logistics sector, but eventually also on related sectors such as the automotive industry. Thus, future research should deal more intensively with user business models, a concept that needs more attention in the scientific literature on business models, especially in relationship to how environmental technologies achieve a wide diffusion.

\section{Acknowledgements}

The authors are particularly grateful to Mr. Kai Warneke, one of the owner managers of PMK-Pflegedienst $\mathrm{GmbH}$, for the access he granted us to his firm in order to make the in-depth case study possible. We thank him for his time and support for this academic work. In addition, we are especially thankful to Mr. Ferdinand Revellio and Mrs. Janina Steigerwald for helping us collect and analyse the data underlying this paper. This research was made possible by the Innovation Incubator of Leuphana University Lüneburg, Germany which was funded by the European Regional Development Fund (ERDF) of the European Union (CCI-Code: 2007DE161PO006). Since October 2015, the 
contributions by Erik G. Hansen are funded by the Institute for Integrated Quality Design (IQD) at Johannes Kepler University (JKU) Linz, Austria, which is co-funded by Quality Austria - Trainings, Zertifizierungs und Begutachtungs GmbH, the State of Upper Austria and the JKU.

\section{References}

Abdelkafi, N. and Täuscher, K. (2015) 'Business models for sustainability from a system dynamics perspective', Organization \& Environment, Vol. 29, No. 1, pp.74-96, DOI: $10.1177 / 1086026615592930$.

Abdelkafi, N., Makhotin, S. and Posselt, Th. (2013) 'Business model innovations for electric mobility - what can be learned from existing business model patterns?', International Journal of Innovation Management, Vol. 17, No. 1, pp.1340003-1-1340003-41.

Augenstein, K. (2015) 'Analysing the potential for sustainable e-mobility: the case of Germany', Environmental Innovation and Societal Transitions, March, Vol. 14, pp.101-115.

Bocken, N.M.P., Short, S.W., Rana, P. and Evans, S. (2014) 'A literature and practice review to develop sustainable business model archetypes', Journal of Cleaner Production, 15 February, Vol. 65, pp.42-56.

Bohnsack, R., Pinkse, J. and Kolk, A. (2014) 'Business models for sustainable technologies: exploring business model evolution in the case of electric vehicles', Research Policy, Vol. 43, No. 2, pp.284-300.

Boons, F. and Lüdeke-Freund, F. (2013) 'Business models for sustainable innovation: state-of-the-art and steps towards a research agenda', Journal of Cleaner Production, April, Vol. 45, pp.9-19.

Bozem, K., Nagl, A., Rath, V. and Haubrock, A. (2013) Elektromobilität: Kundensicht, Strategien, Geschäftsmodelle (E-Mobility: Customer Perspective, Strategies, Business Models), Springer Vieweg, Wiesbaden, Germany.

Chesbrough, H. (2006) Open Business Models: How to Thrive in the New Innovation Landscape, Harvard Business School Press, Boston, MA, USA.

Christensen, C.M. (1997) The Innovator's Dilemma: When New Technologies Cause Great Firms to Fail, Harvard Business School Press, Boston, MA, USA.

Christensen, T.B., Wells, P. and Cipcigan, L. (2012) 'Can innovative business models overcome resistance to electric vehicles? Better place and battery electric cars in Denmark', Energy Policy, pp.498-505.

Currie, W.L. (2004) Value Creation from e-Business Models, Elsevier, Amsterdam.

Demil, B., Lecoq, X., Ricart, J.E. and Zott, A. (2015) 'Introduction to the SEJ Special Issue on Business Models: Business Models within the Domain of Strategic Entrepreneurship', Strategic Entrepreneurship Journal, Vol. 9, No. 1, pp.1-11.

Deutsche Post DHL Group (DHL) (2016) Corporate Responsibility Report 2015 [online] http://www.dpdhl.com/en/responsibility/services/downloads.html (accessed 1 September 2016).

Doranova, A., Miedzinski, M., van der Veen, G., Reid, A., Leon, L.R., Ploeg, M., Carlberg, M. and Joller, L. (2012) Business Models for Systemic Eco-Innovations, Final report, February, Technopolis Group [online] http://www.technopolis-group.com/wp-content/uploads/2014/04/ 1524_EcoBM-Eco-Innovation-Business-Models-assessment.pdf (accessed 31 March 2015).

Eisenhardt, K.M. and Graebner, M.E. (2007) 'Theory building from cases: opportunities and challenges', Academy of Management Journal, Vol. 50, No. 1, pp.25-32. 
Enkel, E. and Mezger, F. (2013) 'Imitation processes and their application for business model innovation: an explorative study', International Journal of Innovation Management, Vol. 17, No. 1, pp.1340005-1-1340005-34.

Ernst, C-S., Özel, F., Davies, H., Olschewski, I. and Pieper, M. (2012) 'The development of the emobility supply chain in Europe - results of the European project ENEVATE', European Electric Vehicle Congress (EEVC), 19-22 November, Brussels, Belgium [online] http://www.enevate.eu/Workpackage1/wp1_results.pdf (accessed 16 August 2016).

Gassmann, O., Frankenberger, K. and Czik, M. (2013) Geschäftsmodelle entwickeln: 55 innovative Konzepte mit dem St. Galler Business Model Navigator (Developing Business Models: 55 Innovative Concepts with St. Gallen Business Model Navigator), Carl Hanser Verlag, Munich, Germany.

Gunderson, G.A. (2013) 'Ecopreneurship', in Idowu, S.O. et al. (Eds.) Encyclopedia of Corporate Social Responsibility, pp.909-915, Springer, Berlin and Heidelberg, Germany.

Hannon, M.J., Foxon, T.J. and Gale, W.F. (2013) 'The co-evolutionary relationship between energy service companies and the UK energy system: implications for a low-carbon transition', Energy Policy, October, Vol. 61, pp.1031-1045.

Hansen, E.G. and Klewitz, J. (2012) 'The role of an SME's green strategy in public-private eco-innovation initiatives: the case of Ecoprofit', Journal of Small Business and Entrepreneurship, Vol. 25, No. 4, pp.451-477.

Hansen, E.G., Große-Dunker, F. and Reichwald, R. (2009) 'Sustainability innovation cube a framework to evaluate sustainability-oriented innovations', International Journal of Innovation Management, Vol. 13, No. 4, pp.683-713.

Henzelmann, T. and Grünenwald, S. (2011) 'R\&D innovation: developing system solutions', in Berger, R. (Ed.): Green Growth, Green Profit- How Green Transformation Boosts Business, pp.223-235, Palgrave Macmillan, New York.

Hockerts, K. and Wüstenhagen, R. (2010) 'Greening Goliaths versus emerging Davids - theorizing about the role of incumbents and new entrants in sustainable entrepreneurship', Journal of Business Venturing, Vol. 25, No. 5, pp.481-492.

International Energy Agency (IEA) (2012) EV City Casebook [online] http://www.iea.org/ publications/freepublications/publication/EVCityCasebook.pdf (accessed 16 August 2016).

Isaak, R. (1998) Green Logic: Ecopreneurship, Theory and Ethics, Greenleaf Publishing, Sheffield, UK.

Johnson, M.W. (2010) Seizing the White Space: Business Model Innovation for Growth and Renewal, Harvard Business Review Press, Boston, MA, USA.

Johnson, M.W., Christensen, C.M. and Kagermann, H. (2008) 'Reinventing your business model', Harvard Business Review, December, Vol. 86, No. 12, pp.51-59.

Klewitz, J. and Hansen, E.G. (2014) 'Sustainability-oriented innovation of SMEs: a systematic review', Journal of Cleaner Production, 15 February, Vol. 65, pp.57-75.

Kley, F., Lerch, C. and Dallinger, D. (2011) 'New business models for electric cars - a holistic approach', Energy Policy, Vol. 39, No. 6, pp.3392-3403.

Lambing, P. and Kuehl, C. (1997) Entrepreneurship, Prentice Hall, Upper Saddle River, NJ, USA.

Lüdeke-Freund, F. (2009) Business Model Concepts in Corporate Sustainability Contexts: From Rhetoric to a Generic Template for 'Business Models for Sustainability', Centre for Sustainability Management (CSM), Leuphana University of Lüneburg, Lüneburg, Germany.

Markides, C.C. and Geroski, P.A. (2005) Fast Second - How Smart Companies Bypass Radical Innovation to Enter and Dominate New Markets, Wiley, San Francisco, CA, USA.

Martins, L.L., Rindova, V.P. and Greenbaum, B.E. (2015) 'Unlocking the hidden value of concepts: a cognitive approach to business model innovation', Strategic Entrepreneurship Journal, Vol. 9, No. 1, pp.99-117. 
Morris, M., Schindehutte, M. and Allen, J. (2005) 'The entrepreneur's business model: toward a unified perspective', Journal of Business Research, Vol. 58, No. 6, pp.726-735.

Nationale Plattform Elektromobilität (2014) Forschungsbericht 2014 - Bilanz der Marktvorbereitung (Research Report 2014 - Drawing a Balance of the Market Preparation Phase), Bundesministerium für Verkehr und digitale Infrastruktur, Berlin [online] https://www.bmbf.de/files/NPE_Fortschrittsbericht_2014_barrierefrei.pdf (accessed 15 November 2015).

Noci, G. and Verganti, R. (1999) 'Managing 'green' product innovation in small firms', $R \& D$ Management, Vol. 29, No. 1, pp.3-15.

Parrish, B.D. (2010) 'Sustainability-driven entrepreneurship: principles of organization design', Journal of Business Venturing, Vol. 25, No. 5, pp.510-523.

Riedel, H., Wettlaufer, R., Reulein, D. and Pohl, E. (2014) Der Arbeitsmarkt für Betriebswirte (The Job Market for Business Management Graduates), Springer Gabler, Wiesbaden, Germany.

Rogers, M.E. (2003) The Diffusion of Innovations, 5th ed., Free Press, New York.

Schaltegger, S. (2002) 'A framework for ecopreneurship - leading bioneers and environmental managers to ecopreneurship', Greener Management International, Summer, Vol. 38, pp.45-58 [online] http://www.greenprof.org/wp-content/uploads/2010/06/A-Framework-forEcopreneurship.pdf (accessed 22 August 2017).

Schaltegger, S. (2010) 'A framework and typology of ecopreneurship: leading bioneers and environmental managers to ecopreneurship', in Schaper, M. (Ed.): Making Ecopreneurs: Developing Sustainable Entrepreneurship, 2nd ed., pp.75-94, Gower, Farnham, UK; Burlington, USA.

Schaltegger, S. and Wagner, M. (2008) 'Types of sustainable entrepreneurship and conditions for sustainability innovation: from the administration of a technical challenge to the management of an entrepreneurial opportunity', in Wüstenhagen, R. et al. (Eds.): Sustainable Innovation and Entrepreneurship, pp.27-48, Edward Elgar, Cheltenham, UK; Northampton, USA.

Schaltegger, S., Hansen, E.G. and Lüdeke-Freund, F. (2016a) 'Business models for sustainability: origins, present research, and future avenues', Organization \& Environment, Vol. 29, No. 1, pp.3-10.

Schaltegger, S., Lüdeke-Freund, F. and Hansen, E.G. (2016b) 'Business models for sustainability: a co-evolutionary analysis of sustainable entrepreneurship, innovation, and transformation', Organization \& Environment, Vol. 29, No. 3, pp.264-289 [online] https://doi.org/10.1177/1086026616633272.

Schaltegger, S., Lüdeke-Freund, F. and Hansen, E. (2012) 'Business cases for sustainability: the role of business model innovation for corporate sustainability', International Journal of Innovation \& Sustainable Development, Vol. 6, pp.95-119.

Schaper, M. (2002) 'The essence of ecopreneurship', Greener Management International, Summer, Vol. 38, pp.26-30.

Schaper, M. (Ed.) (2005/2010) Making Ecopreneurs: Developing Sustainable Entrepreneurship, 2nd ed., Gower, Farnham, UK; Burlington, USA.

Scherer, A.G. and Palazzo, G. (2011) 'The new political role of business in a globalized world - a review of a new perspective on CSR and its implications for the firm, governance, and democracy', Journal of Management Studies, Vol. 48, No. 4, pp.899-931.

Shane, S. (2003) A General Theory of Entrepreneurship: The Individual-Opportunity Nexus, Edward Elgar Publishing Limited, Cheltenham, UK; Northampton, MA, USA.

Sosna, M., Trevinyo-Rodrígue, R.N. and Velamuri, S.R. (2010) 'Business model innovation through trial-and-error learning: the Naturhouse case', Long Range Planning, Vol. 43, Nos. 2-3, pp.383-407.

Teece, D.J. (2010) 'Business models, business strategy and innovation', Long Range Planning, Vol. 43, Nos. 2-3, pp.172-194.

von Hippel, E. (1988) The Sources of Innovation, Oxford University Press, New York; Oxford. von Hippel, E. (2005) Democratizing Innovation, MIT Press, Cambridge; London. 
Walley, L., Taylor, D. and Greig, K. (2010) 'Beyond the visionary champion: testing a typology of green entrepreneurs', in Schaper, M. (Ed.): Making Ecopreneur: Developing Sustainable Entrepreneurship, pp.59-74, 2nd ed., Gower, Farnham, UK; Burlington, USA.

Weinberger, N., Jörissen, J. and Schippl, J. (2012) 'Foresight on environmental technologies: options for the prioritisation of future research funding - lessons learned from the project Roadmap Environmental Technologies 2020+', Journal of Cleaner Production, May, Vol. 27, pp.32-41.

Wells, P.E. (2013) Business Models for Sustainability, Edward Elgar, Cheltenham and Massachusetts.

Wells, P. and Nieuwenhuis, P. (2015) 'EV business models in a wider context: balancing change and continuity in the automotive industry', in Beeton, D. and Meyer, G. (Eds.): Electric Vehicle Business Models: Global Perspectives, pp.3-16, Springer, Heidelberg, Germany.

Will, C. and Schuller, A. (2016) 'Understanding user acceptance factors of electric vehicle smart charging', Transportation Research Part C: Emerging Technologies, October, Vol. 71, pp.198-214.

Yin, K.R. (2009) Case Study Research: Design and Methods, 4th ed., Sage, Thousand Oaks, CA, USA. 